9. Півоваров О.А., Ковальова О.С. Дослідження адсорбиійних властивостей зерна при використанні водних розчинів, оброблених контактною нерівноважною плазмою // Вопросы химии и химической технологии. 2011. №5. C.18-21.

10. Вплив плазмохімічно активованих водних розчинів на процеси адсорбцї та десорбції зернового матеріалу у виробництві солоду / Півоваров А.О. // Хранение и переработка зерна. 2013. №9(174). С.56-60.

11. Мелетьєв А.С. Технохімічний контроль виробництва солоду, пива і безалкогольних напоїв / Мелетьєв А.С., Тодосійчук С.Р., Кочова В.М. : за ред. А.С.Мелетьєва. (Підручник). - Вінниия : Нова Книга, 2007. - 392 с.

Надійшла 28.08.2018. До друку 12.09.2018. Рецензія 29.08.2018

Адреса для переписки:

E-mail: livre@i.uaE-mail: tzpsgp@,i.ua E-mail: denkofan@gmail.com

* Department of Technology Storage and Processing of Agricultural Products Dnipro State Agrarian and Economic University 25 Serhiia Yefremova Street, Dnipro, 49600, Ukraine

\title{
PROSPECTS FOR THE USE OF GRAIN RAW MATERIALS IN THE PRODUCTION OF FUNCTIONAL PRODUCTS
}

\begin{abstract} prove the organoleptic properties of bakery, dairy and confectionery. johnsonii, L. plantarum, Bifidobacterium longum, B. breve, B. lactis. metic industries. pharmaceutical industry. functionality of which must be studied.

Interest in the development of technologies for the production of functional products is growing due to their high market potential, which is associated with a number of their protective properties. Functional foods contain substances that have a positive effect on the human body, which makes them the subject of scientific research. Special attention in the development of functional products is paid to increasing their industrial production from various types of raw materials. This approach allows the development of functional products based on regional resources [1-3]. The term "functional nutrition" in the scientific literature appeared in Japan in 1989, the main approaches to the definition of which correspond to three characteristics: forming part of the daily diet; components must be natural (of natural origin); along with the nutritional value should contribute to the regulation of any function of the body. The creation and introduction of functional products into produc-
\end{abstract}

The development of new physiologically functional food products is a prospective direction for world food products market. The inclusion of functional ingredients in food can increase the biological value of products that are already familiar to the consumer, as well as expand the range of products offered. Physiological activity of cereal's ingredients varies widely, there are: anticancer, antiallergic, antioxidant properties, prebiotic, immunostimulating effects, etc. Moreover, the cereal's ingredients can im-

Cereals can be used as a prebiotics: fermentable substrates for the growth of probiotic microbiota. It is scientifically proven that grain's nondigestible carbohydrates stimulate the growth of Lactobacillus acidophilus, L. casei, L. reuteri, L. rhamnosus, L.

Cereals contain water-soluble fibre, such as $\beta$-glucan and arabinoxylan, oilgosaccharides, such as xylo- and fructooligosaccharides and resistant starch, which have a wide application as prebiotic preparations. Furthermore, cereals as wheat, rye and rice contain polyphenols (benzoic and cinnamic acid derivatives) that are used both in the food industry as antioxidants, dyes, flavors of natural origin and in the compositions of physiologically functional ingredients, as well as in the pharmaceutical and cos-

Thus using cereals as a raw material for functional ingredients obtaining is a perspective in biotechnology, food and

The modification of cereals processing technologies also will allow produce insufficiently studied prebiotic compounds, the

Keywords: cereals, probiotics, prebiotics, modified polysaccharides, functional products

tion is one of the areas of the humanistic program of human nutrition proclaimed by the UN $[1,2]$.

The use of biologically active additives (BAA) allows filling the shortage of essential nutrients, increasing the nonspecific resistance of the organism to the effects of adverse factors, carrying out immune correction, individualizing the most nutrition. Among the existing dietary supplements, widespread and rapid development are observed among probiotics and prebiotics.

Probiotic products are defined as products that contain a single or mixed culture of microorganisms that positively affect the health of consumers and correct the balance of the intestinal microbiota [20]. Their physiological effect has been widely studied by domestic and foreign scientists both in vitro studies and through clinical animal tests, namely lactose metabolism, control of gastrointestinal infections, suppression of cancer, reduction of serum cholesterol and immune stimulation $[19,24]$. In probiotic preparations, mainly the following 
cells are used: Lactobacillus (Lactobacillus acidophilus, $L$. casei, L. reuteri, L. rhamnosus, L. johnsonii and $L$. plantarum) u Bifidobacterium (Bifidobacterium longum, $B$. breve, $B$. lactis) [41]. Introduction of probiotic strains into traditional food products is especially widespread in the dairy industry, as a result of which new types of fermented milk and cheeses are produced [27].

Prebiotic is a food ingredient that is not hydrolyzed by human digestive enzymes in the upper gastrointestinal tract, but selectively stimulates the growth and/or activity of the normal intestinal microbiota [23]. Prebiotics are dietary fibers obtained from the cell walls of plants by hydrolysis. They are easily fermented by specific intestinal bacteria, such as bifidobacteria and lactobacilli, increasing the population of cells with the simultaneous formation of short-chain fatty acids. These acids, especially butyrate, acetate and propionate, provide metabolism and lower the $\mathrm{pH}$ of the intestine [40]. A number of studies indicate that prebiotics lower blood cholesterol and glucose levels, the risk of developing cancer, diabetes, cardiovascular diseases and obesity $[16,18,28,34,42]$. Fig. 1 illustrates the main physiological effects of prebiotics on the human body.

\section{Functional products based on cereals}

Cereals were investigated as a potential source for the production of functional products. More than $73 \%$ of the total cultivated area is used for growing crops, they provide more than $60 \%$ of world food production. The functional properties of cereals are associated with various minerals, vitamins and numerous biologically active compounds present in the grain. Cereals contain such phytochemicals as phenolic antioxidants, saponins, sterols, and phytoestrogens. Part of the health effects of cereals is due to the structural features of the complexes of dietary fiber present in them with phenolic compounds, lignin, and other bioactive molecules [4]. The most important physiological and functional components of cereals are shown in Fig. 2.

Use of cereals or cereal components in functional food products:

- as fermentable substrates for the growth of probiotic microorganisms, especially lactobacilli and bifidobacteria;

- as dietary fiber;

- as prebiotics;

- as encapsulating materials for probiotics in order to increase their stability.

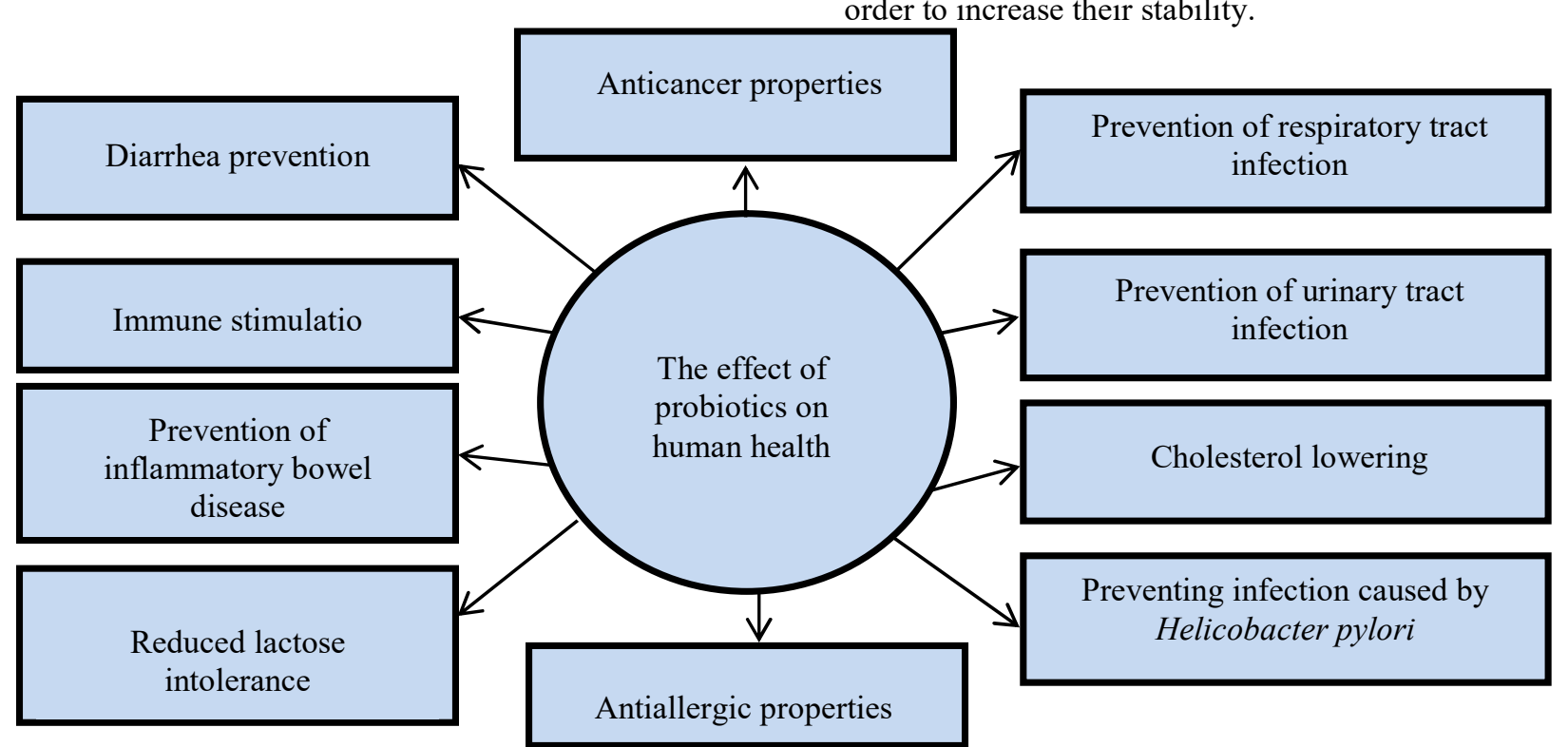

Figure 1 - The main physiological effects of prebiotics on the human body [15]

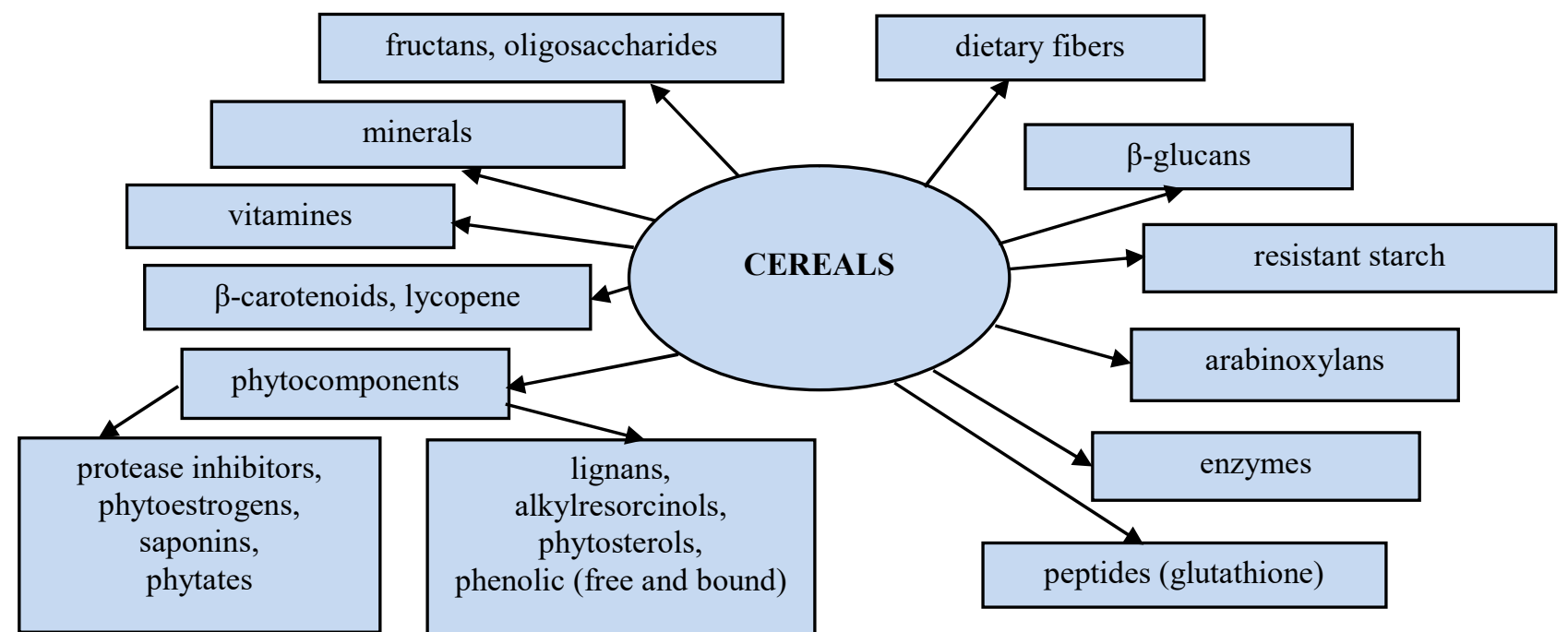

Figure 2 - The most important physiological and functional components of cereals 


\section{Cereals - substrates for probiotics}

The fermentation of cereals with lactobacilli in Asia and Africa is a common processing method for the production of food: beverages, liquid and thick cereals. Despite some differences in the technology of preparation of such products, there are general approaches. Grain cereals (corn, sorghum, millet) are soaked in water for 0.5 to 2 days, which helps to soften the grain before grinding, sent for grinding, and bran is easily removed from the resulting suspension by sieving. Then, suspension is carried out for 1-3 days, during which the crushed grain is fermented by lactobacilli.

In European countries, cereals (wheat and rye) are used in the baking industry for the production of leaven. During the preparation of the leaven, the starter culture of lactobacilli is introduced, the fermentation lasts until the accumulation of the probiotic culture in the volume of more than $10^{9} \mathrm{CFU} / \mathrm{g}$, and the ratio of lactic acid bacteria to yeast is usually 100: 1 [38].

Carbohydrates of cereals have a high prebiotic effect and their inclusion in a number of foods not only expands the range, but also increases their biological value. Thus, in recent years, they have been particularly widespread in sour-milk products. However, when developing new technologies for fermented food products, technological aspects should be taken into account: chemical composition and processing methods of cereals, starter culture, stability of the number of probiotic cells during the shelf life, as well as organoleptic properties and nutritional value of the final product.

In order for a probiotic product to be considered functional, the concentration of lactic and/or bifidobacteria must be at least $107 \mathrm{CFU} / \mathrm{g}$. That is why probiotic strains should have a high adaptability to the substrate, growth rate and viability $[27,41]$.

Lactobacilli and bifidobacteria for normal growth require a number of nutrients: carbohydrates, amino acids, peptides, fatty acids, minerals, derivatives of nucleic acids and vitamins. The content of vitamins and minerals of cereals are given in Table 1, 2 .

Suggested the use of lactobacilli fermented liquid oatmeal for enteral nutrition [31]. Testing of several strains of hetero-and homofermentative probiotic lactobacilli showed that L. acidophilus showed the lowest rates of reducing the $\mathrm{pH}$ and the number of viable cells in the finished product. High scores showed L. plantarum и L. reuteri $3 \cdot 10^{9}$ and $1 \cdot 10^{9} \mathrm{CFU} / \mathrm{g}$, respectively. Adding barley malt to the porridge increased the rate of decrease in $\mathrm{pH}$ and the total amount L. acidophilus $10^{9} \mathrm{CFU} / \mathrm{g}$ in the final product $[15,32]$. In the research [27] strains $L$. reuteri, L. plantarum, L. acidophilus and L. fermentum, were cultivated in extracts of malt, barley and wheat (Table 3). Malt medium showed better cell growth than barley and wheat, due to the increased content of maltose, sucrose, glucose, fructose and free amino nitrogen [26]. Thus, combining carbon and nitrogen sources for probiotic cultures gives greater results than using a specific cereal grain.

Just do not forget about the organoleptic characteristics of the finished product. Functional products using a single probiotic strain have a sour smell and taste, so it is recommended to add Streptococcus thermophilus and $L$. delbrueckii or other strains that produce the desired aromatic substances [38]. During the fermentation of grain in production, L. sanfransisco is most often mixed with Sacharomyces exiguus or Candida milleri, thereby improving the organoleptic properties of the finished product [25].

Table 1 - The content of water soluble vitamins in whole grain cereal flour (mg/kg)

\begin{tabular}{|c|c|c|c|c|c|c|c|c|}
\hline Vitamines & Wheat & Rye & Barely & Maize & Oat & Rice & Buckwheat & Millet \\
\hline Thiamine, $\mathrm{B}_{1}$ & 3,9 & 3,3 & 1,6 & 3,3 & 4,2 & 0,7 & 3,9 & 7,3 \\
\hline Riboflavin, $\mathrm{B}_{2}$ & 0,8 & 1,1 & 0,7 & 1,1 & 1,2 & 0,3 & 1,0 & 3,8 \\
\hline Niacin, $B_{3}$ & 56 & 17 & 55 & 57 & 8 & 14 & 3,5 & 2,3 \\
\hline Pantothenic acid, $\mathrm{B}_{5}$ & 6,8 & 4,9 & 5 & - & 15 & 5,5 & 14,5 & - \\
\hline Pyridoxin, $\mathrm{B}_{6}$ & 3,4 & 2,8 & 3 & 2,3 & 14,4 & 1,1 & 4,0 & 7,5 \\
\hline Folate, $\mathrm{B}_{9}$ & 0,5 & 0,7 & 0,3 & 0,2 & 0,45 & 0,3 & 0,3 & 0,3 \\
\hline Biotin, H & 0,07 & 0,06 & - & - & 0,19 & 0,03 & - & - \\
\hline
\end{tabular}

Table 2 - The content of minerals in whole grain $(\mathrm{mg} / \mathrm{kg})$

\begin{tabular}{||l||l||l||l||l||l||l||l||l||l||}
\hline \hline Minerals & Wheat & \multicolumn{1}{|c|}{ Rye } & Barely & \multicolumn{1}{|c|}{ Maize } & Oat & Rice & Buckwheat & Millet & Sorghum \\
\hline \hline $\mathrm{P}$ & 1170 & 3010 & 2650 & 990 & 4110 & 1030 & 1550 & 2400 & 350 \\
\hline \hline $\mathrm{K}$ & 1560 & 4380 & 3280 & 1200 & 4000 & 1500 & 2400 & 2200 & 240 \\
\hline \hline $\mathrm{Mg}$ & 270 & 930 & 670 & 470 & 1170 & 350 & 1010 & 1000 & 180 \\
\hline \hline $\mathrm{Ca}$ & 180 & 330 & 270 & 60 & 530 & 60 & 110 & 100 & 30 \\
\hline $\mathrm{Na}$ & 20 & 50 & 40 & 10 & 40 & 20 & 10 & - & 5 \\
\hline $\mathrm{Zn}$ & 8 & 28 & 13 & 5 & 30 & 17 & 25 & 34 & 3 \\
\hline \hline $\mathrm{Fe}$ & 12 & 28 & 24 & 11 & 38 & 12 & 15 & 48 & 11 \\
\hline \hline $\mathrm{Mn}$ & 5 & 22 & 13 & - & 58 & 9 & 15 & 7 & 1 \\
\hline \hline $\mathrm{Cu}$ & 1 & 3 & 1 & - & 2 & 2 & 6 & 5 & 0,2 \\
\hline
\end{tabular}


Physiological and functional components of cereals and their physiological effects

\section{Dietary fiber}

According to modern nutrition theory, dietary fibers, along with their characteristic properties, also have high prebiotic potential and selective stimulating effect on the growth of the normal microbiota of the intestinal microorganism, thereby increasing its immune function and reducing the risk of developing diseases of the gastrointestinal tract (GIT), the appearance of ulcers, allergies $[1,2,5]$.

They represent a non-fermentable matrix of cell walls of bran in the digestive tract, which is based on cellulose, hemicellulose, lignin and non-extractable arabinoxylan. The main part of dietary fiber is contained in bran and is removed in the process of peeling and grinding grain. Therefore, it is advisable to give a table of the percentage ratio of bran and germ fractions in cereals as the main source of dietary fiber (Table 3).

Table 3 - The fractions ratio of bran and germ in cereals (\%)

\begin{tabular}{||c||c||c||}
\hline Cereals & Bran & Germ \\
\hline \hline Wheat & $14.0-15.0$ & $2.5-3.0$ \\
\hline \hline Rye & $11.5-12.5$ & $2.7-3.1$ \\
\hline \hline Barely & $28.0-31.0$ & $3.0-3.5$ \\
\hline \hline Oat & $30.0-32,0$ & $4.8-5.1$ \\
\hline \hline Rice & $7.0-7.2$ & $2.0-2.5$ \\
\hline \hline Maize & $5,0-5.5$ & $10.0-11.0$ \\
\hline \hline Buckwheat & $7.5-8.3$ & $3.7-4.1$ \\
\hline \hline Millet & $8,1-8.6$ & $16.8-17.2$ \\
\hline
\end{tabular}

\section{B-Glucan}

$\beta$-Glucans are unbranched polysaccharides formed from glycopyranose residues connected by groups of conjugated $\beta-(1-4)$ bonds and isolated $\beta-(1-3)$ bonds. Isolated $\beta-(1-4)$ bonds are not found in the structure of grain $\beta$-glucans, most $\beta-(1-4)$ bonds are arranged in groups of 2 or 3 . The main structural fragment is cellotriose chains and cellotetraose residues connected by single $\beta-(1-3)$ connections. The main chain of $\beta$-glucan, thus, resembles the structure of cellulose, but contains an inflection in the position of $\beta-(1-3)$ binding. These kinks destroy the strong hydrogen bonds that are commonly found in cellulose, therefore, unlike cellulose, grain $\beta$ glucans are soluble in water $[1,2,3]$.

$\beta$-Glucans are divided into high molecular weight up to $3000 \mathrm{kDa}$ and low molecular weight up to 9 $\mathrm{kDa}$. In addition to molecular weight, they differ in the degree of gelation and structural bonds. In addition, the ability of $\beta$-glucans of oats and barley to selectively stimulate the growth of lactic and bifidobacteria in experiments in vitro and in vivo was repeatedly confirmed [29].

It is known that barley and oats lead in the content of $\beta$-glucan; its content varies from $3-11 \%$ to $3-7 \%$ by dry weight, respectively. $\beta$-glucans are concentrated in the aleurone layer and the endosperm of barley, oats, and wheat. $[30,44,45]$. Despite the fact that the glucan content in wheat does not exceed $1 \%$, grinding of the weevil leads to the separation of the aleurone layer, which makes it possible to develop the technology for processing secondary products of wheat processing into $\beta$-glucans.

To date, $\beta$-glucan concentrates have found worldwide use as stabilizers and rheological correctors for food systems, as well as prophylactic and therapeutic drugs prescribed for various diseases. The use of symbiotic complexes based on $\beta$-glucans, increases the stability of probiotics and allows for more efficient use of functional ingredients with their inclusion.

\section{Resistant starch}

Resistant or stable starch refers to functional dietary fiber that plays an important role in the physiology of the gastrointestinal tract. Like many oligosaccharides, especially fructooligosaccharides, it is not digested in the human body; however, it is a source of fermentable carbohydrates for the intestinal microbiota. Another advantage of resistant starch is the synthesis of essential metabolites, including short-chain fatty acids in the colon. In addition to therapeutic effects, it has more attractive organoleptic properties (appearance, texture, and aftertaste) in comparison with traditional dietary fibers [33]. Today, there are already technologies for obtaining physiologically functional ingredients from resistant starch, namely prebiotics aimed at reducing the risk of intestinal diseases. Resistant starch can be divided into four types, but its natural forms are often destroyed during the technological operations of cooking [46]. In its natural form, it is found in cereals, as well as in heattreated starch-containing products. Therefore, when obtaining resistant starch, acid hydrolysis, hydrothermal treatment, heating, retrogradation, extrusion cooking, chemical modification and repolymerization are used $[16,21,39,43,46]$.

\section{Oligosaccharides}

Oligosaccharides such as lactulose, fructooligosaccharides, transgalacto-oligosaccharides have been used in the food industry since the 1980s [19]. In the food industry, oligosaccharides are used as bifidogenic substances, and some are contained in baby foods as an analogue of human milk oligosaccharides [39]. A subsequent study of their technological and physiological properties led to the expansion of their areas of application. Today, oligosaccharides are used in food, pharmaceutical, cosmetic and other industries. Special attention of scientists today attract oligosaccharides obtained by the hydrolysis of xylan - xylooligosaccharides (XOS).

XOS are most widely used as ingredients in functional foods. They are added to the composition of soft drinks, tea, dairy products, confectionery, jams, bee products, gerodietic and other products for children [23, 45].

In the food industry, XOS are used in the production of low-calorie sweeteners like xylitol. Thus, they enhance the sweet taste without altering other organoleptic characteristics. Stability in a wide range of temperatures and $\mathrm{pH}$, high prebiotic effect allows using XOS as an ingredient of synbiotic products. Unassimilated oligosaccharides are the matrix for immobilization of probiotic bacteria. The resulting synbiotic drugs are sent to the colon undamaged [45]. 
In the pharmaceutical industry, XOS is used in the composition of antiviral and anticancer drugs. They are added in the preparation of micro- and nanoparticles, hydrogels for drug delivery, as well as the treatment and prevention of gastrointestinal disorders [46]. Immunomodulatory, anticarcinogenic and antiallergic activities make it possible to include XOS as a component of the respective drugs.

XOS is also added to pet food and fish food. They are used in agriculture as a yield enhancer, ripening agents and growth-promoting factor and growth accelerator [46].

\section{Polyphenols}

Antioxidants are concentrated in the outer shell of the grains of cereals, where their content reaches $80 \%$ of the total amount in the grain. This causes the growth of production volumes for the population of bread products from whole-grain flour or with the addition of bran, as well as the intensive use of native antioxidants for other purposes [7].

Table 4 - Main components of wheat bran and their physiological effects

\begin{tabular}{|c|c|c|c|c|}
\hline Component & $\begin{array}{l}\text { Content, } \% \\
\text { dry matter }\end{array}$ & Functionality & Health effects & \\
\hline $\begin{array}{l}\text { Carbohydrates: } \\
\text { Alimentary fiber }\end{array}$ & $\begin{array}{l}65.0-75.0 \\
41.0-63.0\end{array}$ & $\begin{array}{l}\text { Increases viscosity in the } \\
\text { intestine and reduces } \\
\text { postpradial glycemic index }\end{array}$ & $\begin{array}{l}\text { Laxative effect, reduces choles- } \\
\text { terol in the blood, carries out a } \\
\text { detoxification effect, prevents } \\
\text { colon cancer }\end{array}$ & 18 \\
\hline Arabinoxylans & $11.0-23.0$ & $\begin{array}{l}\text { Estrogenic effect, antitumor } \\
\text { properties }\end{array}$ & $\begin{array}{l}\text { Reduces the risk of cardiovascular } \\
\text { disease and type } 2 \text { diabetes }\end{array}$ & $\begin{array}{l}18, \\
20\end{array}$ \\
\hline $\begin{array}{l}\text { Resistant } \\
\text { (starch) }\end{array}$ & $\begin{array}{c}5.6-8.9 \\
(17.0-37.4)\end{array}$ & $\begin{array}{l}\text { Increased viscosity in the } \\
\text { intestine, the formation of } \\
\text { metabolites, including short- } \\
\text { chain fatty acids }\end{array}$ & Prebiotic effect & 22 \\
\hline$\beta$-Glucans & $3.1-4.0$ & $\begin{array}{l}\text { Increases viscosity in the } \\
\text { intestine, reduces the glyce- } \\
\text { mic index }\end{array}$ & $\begin{array}{l}\text { Reduces the risk of cardiovascular } \\
\text { diseases, reduces blood cholester- } \\
\text { ol and glycemic index, shows } \\
\text { prebiotic properties }\end{array}$ & 23 \\
\hline $\begin{array}{l}\text { Oligosaccharides } \\
\text { (stachyose, raffinose, } \\
\text { fructooligosaccharides) }\end{array}$ & $2.9-3.7$ & $\begin{array}{l}\text { Improves the organoleptic } \\
\text { properties of the product }\end{array}$ & $\begin{array}{l}\text { Growth stimulants of } \text { GIT } \\
\text { microbiota }\end{array}$ & \\
\hline $\begin{array}{l}\text { Phytochemicals, } \\
\text { mcg/g: } \\
\text { Lignans } \\
\text { Alkylresorcinols } \\
\text { Phytosterols } \\
\text { Phenolic compounds } \\
\text { (ferulic acid) } \\
\text { Related phenolic com- } \\
\text { pounds } \\
\text { Saponins and } \\
\text { capsacins }\end{array}$ & $\begin{array}{c}2.550-11.350 \\
600-1.000 \\
400-1,250 \\
340-1.900 \\
1.300-1.900\end{array}$ & $\begin{array}{l}\text { Anticarcinogenic and antiox- } \\
\text { idant properties, lipid oxida- } \\
\text { tion inhibitors } \\
\text { Inhibits cholesterol sorption } \\
\text { Inhibits cholesterol sorption } \\
\text { in the small intestine, antiox- } \\
\text { idants }\end{array}$ & $\begin{array}{l}\text { Reduce the risk of prostate and } \\
\text { breast cancer } \\
\text { Produce plasma cholesterol } \\
\text { Reduce the risk of colon cancer } \\
\text { and cardiovascular diseases } \\
\text { Protease inhibitors reduce the risk } \\
\text { of developing colon, lung, liver, } \\
\text { pancreas and esophagus cancers. }\end{array}$ & $\begin{array}{l}25 \\
26 \\
27\end{array}$ \\
\hline $\begin{array}{l}\text { Peptides } \\
\text { (L-glutathione) }\end{array}$ & & $\begin{array}{l}\text { Antioxidant properties, in- } \\
\text { creases the digestibility of } \\
\text { certain vitamins, protects } \\
\text { white blood cells, partici- } \\
\text { pates in the synthesis of } \\
\text { leukotrients, cleanses the } \\
\text { liver, starts self-destruction } \\
\text { mechanism (apoptosis) in } \\
\text { cancer cells }\end{array}$ & $\begin{array}{l}\text { Reduces depression and apathy, } \\
\text { autoimmune disorders, chronic } \\
\text { kidney damage, malignant tumors }\end{array}$ & 29 \\
\hline Enzymes & & Help digestion & $\begin{array}{l}\text { Reduces obesity, allergies, vari- } \\
\text { ous diseases of the gastrointesti- } \\
\text { nal tract }\end{array}$ & 31 \\
\hline
\end{tabular}


Polyphenols are a group of several classes of weakly acidic chemical compounds that contain several aromatic (benzene) rings directly bonded to one or more hydroxyl phenolic groups. They are secondary metabolites of plants, formed as a result of the flow of shikimate pathway. Phenolic acids contained in barley kernels from 450 to $1346 \mu \mathrm{g} / \mathrm{g}$, maize $601 \mu \mathrm{g} / \mathrm{g}$, oats $472 \mu \mathrm{g} / \mathrm{g}$, rice $197-376 \mu \mathrm{g} / \mathrm{g}$, rye $1,362-1,366 \mu \mathrm{g} / \mathrm{g}$, sorghum $385-746$ $\mu \mathrm{g} / \mathrm{g}$, wheat $1342 \mu \mathrm{g} / \mathrm{g}$ and oat bran $651 \mu \mathrm{g} / \mathrm{g}$, rye 4190 $\mu \mathrm{g} / \mathrm{g}$, wheat up to $4527 \mu \mathrm{g} / \mathrm{g}$ [7].

According to studies by foreign and domestic scientists, phenolic antioxidants exhibit a protective effect against the oxidative effect of copper on DNA in the calf thymus. Similarly, barley extracts of free and bound phenolic substances inhibit the breaking of the chain of DNA molecules. Barley contains various phenolic antioxidants: benzoic and cinnamic acid derivatives, flavanols, flavones, flavanones, chalcones, proanthocyanides, quinones, and aminophenolic compounds present in free and bound forms. At the same time, barley contains bound ferulic and p-coumaric acid in much smaller quantities than other grains $-50 \mathrm{mg} / \mathrm{kg}$ and $3 \mathrm{mg} / \mathrm{kg}$, respectively. Anthocyanins are also contained in barley grain $4 \mu \mathrm{g} / \mathrm{g}$, corn $93-965 \mu \mathrm{g} / \mathrm{g}$, black rice $2283 \mu \mathrm{g} / \mathrm{g}$, sorghum up to $944 \mu \mathrm{g} / \mathrm{g}$, wheat from 13 to $153 \mu \mathrm{g} / \mathrm{g}[7,13]$.

Today, polyphenols are used both in the food industry as antioxidants, dyes, flavors of natural origin and in the compositions of physiologically functional ingredients, as well as in the pharmaceutical and cosmetic industries.

Wheat bran is of the greatest interest as a raw material for the production of physiological and functional ingredients, as they are a by-product of the pro- cessing of wheat into flour. Wheat is the most common cereal grown on the territory of Ukraine, which means solving the problem of bran utilization is relevant. Therefore, it was advisable to present a general table of the main components of wheat bran and their physiological effects (Table 4).

\section{Conclusion}

Cereals are the source of a wide range of substrates-growth promoters for the probiotic human microbiota. Such a variety of physiological effects, organoleptic characteristics and methods of production requires a systematic approach for determining endogenous and technological factors that promote growth and, more importantly, the survival of probiotic microorganisms in vitro and in vivo. The combination of probiotic cultures and physiological and functional substances can also improve the organoleptic properties of the product.

In addition, the selection of dietary fiber, resistant starches, $\beta$-glucans, oligosaccharides and antioxidants from various types of grain or by-products of their processing is a promising direction in biotechnology, food and pharmaceutical industry.

The development of new technologies for obtaining physiologically functional ingredients has the advantage that food manufacturers can increase the biological value of products that are already familiar to the consumer, as well as expand the range of products offered. Cereals do not only have the ability to stimulate the growth of lactic and bifidobacteria, deliver them to the human intestine, but also contain insufficiently studied prebiotic compounds, the functionality of which must be studied.

\section{REFERENSES}

1. Bobreneva, I.V. Podhodi k sozdaniyu fynktcionalnih produktov pitaniya [Text] / I.V. Bobreneva Sankt-Peterburg, $2012 .-465 \mathrm{~s}$.

2. Kaprelyants, L.V. Funktcionalni produkti [Text] / L.V. Kaprelyants, K.G. Iorgachova. - Odesa, 2003. - $312 \mathrm{~s}$.

3. Van, L.A. Bifidobacterium glycoside hydrolases and (potential) prebiotics [Text] / L.A. Van, A.G. Voragen // Innov. Food Sci. Emerg. Technol.. - 2008. - Vol. 9, Is. . - P. 401-407.

4. Kaprelyants, L.V. Biologicheski aktivnie fitoveshchestva zernovih [Text] / L.V. Kaprelyants // Zernovi produkti i kombikormi. 2010. - № 2. - S. 13-15.

5. Kostyrina, K.V. Izuchenie fermentativnou kinetiki proteinsoderzashchego siriya kak osnovopolagaiyshchego biotehnologicheskogo protsesa pri polucenii novih produktov [Text] / K.V. Kostyrina, M.E. Tsibizovz // Vestnik AGTU . - 2007. Vol. 38, № 3. - S. 125-129.

6. Shelembe, J.S. Phenolic compounds in aqueous extracts of marama bean [Text] / J.S. Shelembe. -, 2012. -162 p.

7. Gaupta, P.K. A Review on Xylooligosaccharides [Text] / P.K. Gaupta, P. Agrawal, P. Hegde // International Research Journal of Pharmacy. - 2012. - Vol. 3, Is. 8. - P. 71-74.

8. Kaprelyants, L.V. Prebiotiki himiya, tehnologiya, primenenie [Text]: monografiya /L.V. Kaprelyants,. - Kiev: EnterPrint, 2015. - T. 1. - 252 s. -978-966-7857-30-1.

9. Xylooligosaccharide - a valuable material from waste to taste: a review [Text] / P.K. Gaupta, P. Agrawal, P. Hegde [et al.] // Journal of Environmental Research And Development. - 2016. - Vol. 10, Is. 3. - P. 555-563.

10. Nuanke, B. Bioactive compounds in grain [Tекст] / B. Nuanke // Report of the graduate assignment for the study Nutrition and Dietetic at the HanzeHogeschool : мamepuarbl, University Medical Center Groningen -, 2008. - C. 97

11. Kaprelyants, L.V. Biologicheski aktivnie fitoveshchestva zernovih [Teкcm] / L.V. Kaprelyants, // Zernovie produkti I kombikorma. - 2010. - № 2. - S. 13-15.

12. Kaprelyants, L.V. Fitokomponenti zernovogo siriya: stroenie, svoystva, primenenie [Text] / L.V. Kaprelyants, E.D. Zhurlova // Harchova nauka i tehnologiya. - 2013. - № 4. - S. 3-7.

13. Fillips, G.O. Spravochnik po gidrokolloidam [Tekst]: spravochnik/G.O. Fillips; pod red. G.O Fillipsa/P.A. Viliamsa; per. angl. Kochetkova A.A.. - : GIORD, 2006. - S. 365.

14. Oats and fat-free milk based functional food product [Text] / M. Bekers, M. Marauska, J. Laukevics [et al.] // Food Biotechnol. 2001. - Is. 15. - P. 1-12

15. Bijlani, R.L. Dietary fibre: consensus and controversy [Text] / R.L. Bijlani // Prog. Food Nutr. Sci. Field . - 1985. - Is. 9. - P. 343-393. 
16. Brumovsky, J.O. Production of boilingstable granular resistant starch by partial acid hydrolysis and hydrothermal treatments of high-amylose maize starch [Text] / J.O. Brumovsky, D.B. Thompson // Cereal Chem. - 2001. - Vol. 78, Is. . - P. 680-689.

17. Charalampopoulos, D. Growth studies of potential probiotic lactic acid bacteria in cereal-based substrates [Text] / D. Charalampopoulos, S. Pandiella, C. Webb // J. Appl. Microbiol. - 2002. - Vol. 98, Is. . - P. 851-859.

18. Fernandez, M.L. Soluble fibre and non-digestible carbohydrate effects on plasma lipids and cardiovascular risk [Text] / M.L. Fernandez // Curr. Opin. Lipidol. - 2001. - Vol. 12, Is. . - P. 35-40.

19. Fooks, L.J. Prebiotics, probiotics and human gut microbiology [Text] / L.J. Fooks, R. Fuller, G.R. Gibson // International Dairy Journal. - 1999. - Is. 9. - P. 53-61.

20. Fuller, R. Probiotics in man and animals [Text] / R. Fuller // Journal Appl. Bacteriol. - 1989. - Vol. 66, Is. . - P. $365-378$.

21. Gebhardt, E. Resistant starch-a component in bifunctional high fibre extrudates [Text] / E. Gebhardt, G. Dongowski, M. Huth // Ernaehrung. - 2001. - Vol. 25, Is. . - P. 202-208.

22. Gibson, G.R. Dietary modulation of the human colonic microbiota: introducing the concept of prebiotics [Text] / G.R. Gibson, M.B. Roberfroid // Journal Nutritional. - 1995. - Vol. 125, Is. . - P. 1401-1412.

23. Selective stimulation of bifidobacteria in the human colon by oligofructose and inulin [Text] / G.R. Gibson, E.B. Beatty, X. Wang, J.H. Cummings // Gastroenterology. - 1995. - Vol. 108, Is. . - P. 975-982.

24. Gilliland, S.E. Health and nutritional benefits from lactic acid bacteria [Text] / S.E. Gilliland // FEMS Microbiol. - 1990. - Is. 88. - P. 175-188.

25. Gobbetti, M. The sourdough microflora: interactions of lactic acid bacteria and yeasts [Text] / M. Gobbetti // Trends Food Sci. Technol. - 1998. - Vol. 9, Is. . - P. 267-274.

26. Gobbetti, M. Lactobacillus Sanfransisco a key sourdough lactic acid bacterium: a review [Text] / M. Gobbetti, A. Corsetti // Food Microbiology. - 1977. - Vol. 14, Is. . - P. 175-187.

27. Gomes, A. Bifidobacterium ssp. and Lactobacillus acidophilus: biological, biochemical, technological and therapeutical properties relevant for use as probiotics [Text] / A. Gomes, X. Malcata // Trends Food Sci. Technology. - 1999. - Vol. 10, Is. . - P. 139157.

28. Iwata, N. Additives to food for controlling diabetes and obesity [Text] / N. Iwata, K. Ishiwatari // Jpn. Kokai Tokkyo Koho. 2001. - Vol. 4, Is. . - P. 4-6.

29. Jaskari, J. The effect of oat h-glucan on the growth of selected Lactobacillus spp. and Bifidobacterium spp [Text] / J. Jaskari, H. Salovaara, T. Mattilla-Sandholm // Proceedings of the 25th Nordic Cereal Congress. Univ. Helsinki, Helsinki. - 1993. - Is. . - P. 242-244.

30. Koksel, H. Barley bulgur: effect of processing and cooking on chemical composition [Text] / H. Koksel, M.J. Edney, B. Ozkaya // Journal Cereal Sciencies. - 1999. - Vol. 29, Is. . - P. 185-190.

31. Marklinder, I. Fermentation properties of intestinal strains of Lactobacillus, of a sour dough and of a yoghurt starter culture in an oat-based nutritive solution [Text] / I. Marklinder, $r$. C Lonner. // Food Microbiology. - 1922. - Is. 9. - P. 197-205.

32. Marklinder, I. Fermented oatmeal soup - influence of additives on the properties of a nutrient solution for enteral feeding [Text] / I. Marklinder, C. Lonner // Food Microbiology. - 1994. - Is. 11. - P. 505-513.

33. Extrusion-cooking of cassava starch with different fiber sources: effect of fibers on expansion and physicochemical properties [Text] / H. Martinez, Y. Chang, F. Bustos, F. Sinencio // Adv. Extrusion. - 1999. - Is. . - P. 271-278.

34. McCann, S. Intakes of selected nutrients and food groups and risk of ovarian cancer [Text] / S. McCann, K. Moysich, C. Mettlin // Nutr. Cancer . - 2001. - Vol. 39, Is. . - P. 19-28.

35. Rivero-Urgell, M. Oligosaccharides: application in infant food [Text] / M. Rivero-Urgell, A. Santamaria-Orleans // Early Hum. Dev. - 2001. - Vol. 65, Is. . P. 43-52.

36. Probiotic bacteria: safety functional and technological properties [Text] / M. Saarela, G. Mogensen, R. Fonden [et al.] // Journal Biotechnology. - 2000. - Vol. 84, Is. . - P. 197-215.

37. Lactic Acid Bacteria [Text] / S. Salminen, M. Deighton, Y. Benno, S. Gorbach // Microbiology and Functional Aspects. Marcel Dekker. - 1998. - Is. . - P. 211-253.

38. Salovaara, H. Lactic acid bacteria in cereal-based products [Text] / H. Salovaara // Microbiology and Functional Aspects. Marcel Dekker. - 1998. - Is. . - P. 115-137.

39. Schmiedel, D. . Method for producing resistant starch by heating and retrogradation [Text] / D. Schmiedel, B.J. Konig, G. Jacobasch // PCT Int. - 2000. - Vol. 30, Is. . - P. 30.

40. Sghir, A. Continuous culture selection of bifidobacteria and lactobacilli from human faecal samples using fructooligosaccharide as selective substrate [Text] / A. Sghir, J.M. Chow, R.I. Mackie // Journal Appl. Microbiology. - 1998. - Vol. 85, Is. . - P. 769777 .

41. Shortt, C. The probiotic century: historical and current perspectives [Text] / C. Shortt // Pharmacology of dietary fibre. - 1999. - Vol. 62, Is. . - P. 411-417.

42. Wang, Y. Effect of dietary fibre on diabetes patient [Text] / Y. Wang, Y. Wang, C. Li // Shipin Gongye Keji . - 2001. - Vol. 22, Is. - P. 25-27.

43. Wolf, B. Effects of chemical modification on in vitro rate and extent of food starch digestion: an attempt to discover slowly digested starch [Text] / B. Wolf, L. Bauer, r. Fahey // Journal Agric. Food Chem. - 1999. - Vol. 47, Is. . - P. 4178-4183.

44. Wood, P.J. Physicochemical characteristics and physiological properties of oat [Text] / P.J. Wood // Oat Bran. AACC, Minnesota, USA. - 1993. - Vol. 83, Is. . - P. 83-112.

45. Wood, P.J. Functional foods for health: opportunities for novel cereal processes and products [Text] / P.J. Wood // Cereals: Novel Uses and Processes. Plenum. - 1997. - Is. . - P. 233-239.

46. Yue, P. Resistant starch in food applications [Text] / P. Yue, S. Waring // Cereal Foods World . - 1998. - Vol. 43, Is. . - P. 690695.

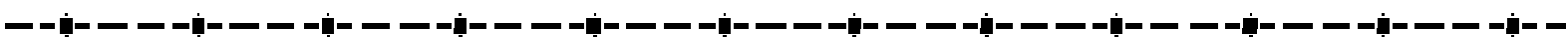


Л. В. КАПРЕЛЬЯНЦ, Д-р техн. наук., профессор, О.Д. ЖУРЛОВА, канд. техн. наук, ассистент, М. Г. БУЖИЛОВ, аспірант

Одеська національна академія харчових технологій, Одеса

\section{ПЕРСПЕКТИВИ ВИКОРИСТАННЯ ЗЕРНОВОЇ СИРОВИНИ У ВИРОБНИЦТВІ ФУНКЦІОНАЛЬНИХ ПРОДУКТІВ}

\section{Анотація}

Розвиток нових фізіологічно функціональних харчових продуктів є перспективним напрямом для світового ринку продуктів харчування. Включення функціональних інгредієнтів у їжу може збільшити біологічну цінність виробів, які вже знайомі споживачеві, а також розширити спектр пропонованих продуктів. Фізіологічна активність інгредієнтів злаків коливається в широких межах: протиракові, протиалергічні, антиоксидантні властивості, пребіотичні, імуностимулюючі ефекти і т. д. Крім того, інгредієнти злаків можуть поліпшити органолептичні властивості хлібобулочних, молочних та кондитерських виробів.

Злаки можна використовувати як пребіотиків: ферментні субстрати для росту мікробата пробіоту. Науково доведено, що непереварні вуглеводи зерна стимулюють ріст Lactobacillus acidophilus, L. casei, L. reuteri, L. rhamnosus, L. johnsonii, L. plantarum, Bifidobacterium longum, B. breve, B. lactis.

Злаки містять водорозчинні волокна, такі як $\beta$-глюкан та арабіноксілан, олігосахариди, такі як ксило- та фруктоолігосахариди та стійкі крохмалі, які широко застосовуються як пребіотичні препарати. Крім того, злаки, як пшениця, жито та рис, містять поліфеноли (похідні бензойної та коричної кислоти), що використовуються як в харчовій промисловості як антиоксиданти, барвники, ароматизатори природного походження, а також у складі фізіологічно функціональних інгредієнтів, а також у фармацевтичному і косметичної промисловості.

Таким чином, використання зернових як сировини для отримання функціональних інгредієнтів є перспективою в галузі біотехнології, харчової та фармацевтичної промисловості.

Модифікація технологій переробки злаків також дозволить виробляти недостатньо вивчені пребіотичні сполуки, функціональність яких повинна вивчатися.

Ключові слова: злаки, пробіотики, пребіотики, модифіковані полісахариди, функціональні продукти.

\section{ЛIТЕРАТУРА}

5. Бобренева, И.В. Подходы к созданию функииональных продуктов питания [Текст] / И.В. БобреневаСанктПетербург, 2012. - 465 c.

6. Капрельяни, Л.В. Функиіональні продукти [Текст] / Л.В. Капрельяни, К.Г. Іоргачова. - Одеса, 2003. - 312 с.

7. Van, L.A. Bifidobacterium glycoside hydrolases and (potential) prebiotics [Text] / L.A. Van, A.G. Voragen // Innov. Food Sci. Emerg. Technol.. - 2008. - Vol. 9, Is. . - P. 401-407.

8. Капрельяни, Л.В. Биологически активные фитовещеества зерновых [Текст] / Л.В. Капрельяни // Зернові продукти і комбікорми. - 2010. - № 2. - С. 13-15.

9. Костюрина, К.В. Изучение ферментативной кинетики протеинсодержсащего сырья как основопологающего биотехнологического процесса при получении новых продуктов [Текст] / К.В. Костюрина, М.Е. Цибизова // Вестник АГТУ . - 2007. - Vol. 38, № 3. - C. 125-129.

10. Shelembe, J.S. Phenolic compounds in aqueous extracts of marama bean [Text] / J.S. Shelembe. -, 2012. - 162 p.

11. Gaupta, P.K. A Review on Xylooligosaccharides [Text] / P.K. Gaupta, P. Agrawal, P. Hegde // International Research Journal of Pharmacy. - 2012. - Vol. 3, Is. 8. - P. 71-74.

12. Капрельяни, Л.В. Пребиотики химия, технология, применетие [Текст]: монография / Л.В. Капрельянц. - Киев: EnterPrint, 2015. - T. 1. - 252 c. -978-966-7857-30-1.

13. Xylooligosaccharide - a valuable material from waste to taste: a review [Text] / P.K. Gaupta, P. Agrawal, P. Hegde [et al.] // Journal of Environmental Research And Development. - 2016. - Vol. 10, Is. 3. - P. 555-563.

14. Nuanke, B. Bioactive compounds in grain [Tексm] / B. Nuanke // Report of the graduate assignment for the study Nutrition and Dietetic at the HanzeHogeschool : мaтериалы, University Medical Center Groningen -, 2008. - C. 97.

15. Капрельяни, Л.В. Биологически активные фитовещества зерновых [Текст] / Л.В. Капрельяни // Зерновые продукты и комбикорма. - 2010. - № 2. - С. 13-15.

16. Капрельяни, Л.В. Фитокомпоненты зернового сырья: строение, свойства, применение [Текст] / Л.В. Капрельяни, Е.Д. Журлова // Харчова наука і технологія. - 2013. - № 4. - С. 3-7.

17. Филлипс, Г.О. Справочник по гидроколлоидам [Текст]: справочник / Г.О. Филлипс; под ред. Г.О Филлипса/П.А. Вильямса; пер. англ. Кочеткова А.А.. - : ГИОРД, 2006. - С. 365.

18. Oats and fat-free milk based functional food product [Text] / M. Bekers, M. Marauska, J. Laukevics [et al.] // Food Biotechnol. - 2001. - Is. 15. - P. 1-12.

19. Bijlani, R.L. Dietary fibre: consensus and controversy [Text] / R.L. Bijlani // Prog. Food Nutr. Sci. Field . - 1985. - Is. 9. P. 343-393.

20. Brumovsky, J.O. Production of boilingstable granular resistant starch by partial acid hydrolysis and hydrothermal treatments of high-amylose maize starch [Text] / J.O. Brumovsky, D.B. Thompson // Cereal Chem. - 2001. - Vol. 78, Is. . - P. 680-689.

21. Charalampopoulos, D. Growth studies of potential probiotic lactic acid bacteria in cereal-based substrates [Text] / D. Charalampopoulos, S. Pandiella, C. Webb // J. Appl. Microbiol. - 2002. - Vol. 98, Is. . - P. 851-859.

22. Fernandez, M.L. Soluble fibre and non-digestible carbohydrate effects on plasma lipids and cardiovascular risk [Text] M.L. Fernandez // Curr. Opin. Lipidol. - 2001. - Vol. 12, Is. . - P. 35-40. 
23. Fooks, L.J. Prebiotics, probiotics and human gut microbiology [Text] / L.J. Fooks, R. Fuller, G.R. Gibson // International Dairy Journal. - 1999. - Is. 9. - P. 53-61.

24. Fuller, R. Probiotics in man and animals [Text] / R. Fuller // Journal Appl. Bacteriol. - 1989. - Vol. 66, Is. . - P. $365-378$.

25. Gebhardt, E. Resistant starch-a component in bifunctional high fibre extrudates [Text] / E. Gebhardt, G. Dongowski, M. Huth // Ernaehrung. - 2001. - Vol. 25, Is. . - P. 202-208.

26. Gibson, G.R. Dietary modulation of the human colonic microbiota: introducing the concept of prebiotics [Text] / G.R. Gibson, M.B. Roberfroid // Journal Nutritional. - 1995. - Vol. 125, Is. . - P. 1401-1412.

27. Selective stimulation of bifidobacteria in the human colon by oligofructose and inulin [Text] / G.R. Gibson, E.B. Beatty, X. Wang, J.H. Cummings // Gastroenterology. - 1995. - Vol. 108, Is. . - P. 975-982.

28. Gilliland, S.E. Health and nutritional benefits from lactic acid bacteria [Text] / S.E. Gilliland // FEMS Microbiol. - 1990. - Is. 88. - P. 175-188.

29. Gobbetti, M. The sourdough microflora: interactions of lactic acid bacteria and yeasts [Text] / M. Gobbetti // Trends Food Sci. Technol. - 1998. - Vol. 9, Is. . - P. 267-274.

30. Gobbetti, M. Lactobacillus Sanfransisco a key sourdough lactic acid bacterium: a review [Text] / M. Gobbetti, A. Corsetti // Food Microbiology. - 1977. - Vol. 14, Is. . - P. 175-187.

31. Gomes, A. Bifidobacterium ssp. and Lactobacillus acidophilus: biological, biochemical, technological and therapeutical properties relevant for use as probiotics [Text] / A. Gomes, X. Malcata // Trends Food Sci. Technology. - 1999. - Vol. 10, Is. . - P. 139-157.

32. Iwata, N. Additives to food for controlling diabetes and obesity [Text] / N. Iwata, K. Ishiwatari // Jpn. Kokai Tokkyo Koho. - 2001. - Vol. 4, Is. . - P. 4-6.

33. Jaskari, J. The effect of oat h-glucan on the growth of selected Lactobacillus spp. and Bifidobacterium spp [Text] / J. Jaskari, H. Salovaara, T. Mattilla-Sandholm // Proceedings of the 25th Nordic Cereal Congress. Univ. Helsinki, Helsinki. - 1993. - Is. . - P. 242-244.

34. Koksel, H. Barley bulgur: effect of processing and cooking on chemical composition [Text] / H. Koksel, M.J. Edney, B. Ozkaya // Journal Cereal Sciencies. - 1999. - Vol. 29, Is. . - P. 185-190.

35. Marklinder, I. Fermentation properties of intestinal strains of Lactobacillus, of a sour dough and of a yoghurt starter culture in an oat-based nutritive solution [Text] / I. Marklinder, r. C Lonner. // Food Microbiology. - 1922. - Is. 9. - P. 197205 .

36. Marklinder, I. Fermented oatmeal soup-influence of additives on the properties of a nutrient solution for enteral feeding [Text] / I. Marklinder, C. Lonner // Food Microbiology. - 1994. - Is. 11. - P. 505-513.

37. Extrusion-cooking of cassava starch with different fiber sources: effect of fibers on expansion and physicochemical properties [Text] / H. Martinez, Y. Chang, F. Bustos, F. Sinencio // Adv. Extrusion. - 1999. - Is. . - P. 271-278.

38. McCann, S. Intakes of selected nutrients and food groups and risk of ovarian cancer [Text] / S. McCann, K. Moysich, C. Mettlin // Nutr. Cancer . - 2001. - Vol. 39, Is. . - P. 19-28.

39. Rivero-Urgell, M. Oligosaccharides: application in infant food [Text] / M. Rivero-Urgell, A. Santamaria-Orleans // Early Hum. Dev. - 2001. - Vol. 65, Is. . - P. 43-52.

40. Probiotic bacteria: safety functional and technological properties [Text] / M. Saarela, G. Mogensen, R. Fonden [et al.] // Journal Biotechnology. - 2000. - Vol. 84, Is. . - P. 197-215.

41. Lactic Acid Bacteria [Text] / S. Salminen, M. Deighton, Y. Benno, S. Gorbach // Microbiology and Functional Aspects. Marcel Dekker. - 1998. - Is. . - P. 211-253.

42. Salovaara, H. Lactic acid bacteria in cereal-based products [Text] / H. Salovaara // Microbiology and Functional Aspects. Marcel Dekker. - 1998. - Is. . - P. 115-137.

43. Schmiedel, D. . Method for producing resistant starch by heating and retrogradation [Text] / D. Schmiedel, B.J. Konig, G. Jacobasch // PCT Int.. - 2000. - Vol. 30, Is. . - P. 30.

44. Sghir, A. Continuous culture selection of bifidobacteria and lactobacilli from human faecal samples using fructooligosaccharide as selective substrate [Text] / A. Sghir, J.M. Chow, R.I. Mackie // Journal Appl. Microbiology. 1998. - Vol. 85, Is. . - P. 769-777.

45. Shortt, C. The probiotic century: historical and current perspectives [Text] / C. Shortt // Pharmacology of dietary fibre. 1999. - Vol. 62, Is. . - P. 411-417.

46. Wang, Y. Effect of dietary fibre on diabetes patient [Text] / Y. Wang, Y. Wang, C. Li // Shipin Gongye Keji . - 2001. - Vol. 22, Is. . - P. 25-27.

47. Wolf, B. Effects of chemical modification on in vitro rate and extent of food starch digestion: an attempt to discover slowly digested starch [Text] / B. Wolf, L. Bauer, r. Fahey // Journal Agric. Food Chem. - 1999. - Vol. 47, Is. . - P. 4178-4183.

48. Wood, P.J. Physicochemical characteristics and physiological properties of oat [Text] / P.J. Wood // Oat Bran. AACC, Minnesota, USA. - 1993. - Vol. 83, Is. . - P. 83-112.

49. Wood, P.J. Functional foods for health: opportunities for novel cereal processes and products [Text] / P.J. Wood // Cereals: Novel Uses and Processes. Plenum. - 1997. - Is. . - P. 233-239.

50. Yue, P. Resistant starch in food applications [Text] / P. Yue, S. Waring // Cereal Foods World . - 1998. - Vol. 43, Is. . - P. 690-695.

Надійшла 02.12.2018. До друку 18.12.2018.

Рецензія 10.12.2018

Адреса для переписки:

ОНАХТ, вул. Канатна, 112, м. Одеса, 65039 